Check for updates

Cite this: RSC Adv., 2017, 7, 24576

Received 23rd December 2016 Accepted 20th April 2017

DOI: $10.1039 / c 6 r a 28636 d$

rsc.li/rsc-advances

\section{Investigation of the corrosion inhibition of carbon steel in hydrochloric acid solution by using ginger roots extract}

\begin{abstract}
H. S. Gadow (iD *a and M. M. Motawea ${ }^{b}$
The inhibitive effect and adsorption behavior of ginger roots extract (GRE) on the corrosion of carbon steel in 1.0 M HCl solution at different temperatures were investigated. The methods used were electrochemical studies (potentiodynamic polarization, electrochemical impedance spectroscopy, and electrochemical frequency modulation), chemical methods (weight loss measurements), surface analysis (atomic force microscopy $[A F M]$ ), and solution analysis (UV-visible spectrophotometric methods, such as Fourier transform infrared $[F T-I R])$. The analysis of the results showed that the inhibition efficiency increased with increasing the concentration of the inhibitor and decreased with temperature. The corrosion rate of carbon steel decreased in the presence of GRE. The corrosion inhibition efficiency increased with GRE concentration to attain $94 \%$ efficiency with $200 \mathrm{ppm}$ at $25{ }^{\circ} \mathrm{C}$. The thermodynamic activation parameters that govern the process were deduced from the temperature dependence. Potentiodynamic polarization curves indicated that the extract behaves as a mixed-type inhibitor. The extract was adsorbed on the carbon steel surface following the Langmuir adsorption isotherm. The adsorption free energy of GRE on carbon steel revealed a physical adsorption of GRE on the metal surface. The results from atomic force microscopy, Fourier transform infrared and UV-visible spectrophotometry analyses support the above inferences.
\end{abstract}

\section{Introduction}

The study of carbon steel corrosion and its inhibition in hydrochloric acid is very important in the field of engineering and in industries involving electrochemical process. ${ }^{1}$ As an example, the refining of crude oil results in a variety of corrosive conditions. Refinery corrosion is generally caused by a strong acid attacking the equipment surface. The other important fields of application are acid pickling, industrial cleaning, acid descaling, oil-well acid in oil recovery, and petrochemical processes. Among the acid solutions, hydrochloric acid is one of the most widely used agents. Acid corrosion inhibitors are organic compounds containing oxygen and sulfur, and nitrogen atoms containing multiple bonds in their molecules through which they can adsorb on the metal surface. The use of inhibitors is one of the best methods of preventing metals against corrosion, especially in acidic media. ${ }^{2-7}$ Inhibition of these organic compounds is attributed to the interactions between the carbon steel surface and the inhibitor molecules via their adsorption. Efforts are now being directed toward the development of safe inhibitor, and in this regard plant extracts have become important as eco-friendly, readily available, economical, renewable sources of effective corrosion inhibitors. ${ }^{8-14}$

${ }^{a}$ Higher Institute for Engineering and Technology, New Demietta, Egypt. E-mail: hsgado73@gmail.com

${ }^{b}$ Delta Higher Institute for Engineering and Technology, Egypt
This study aimed to investigate the inhibitory effect of ginger roots extract (GRE) as a corrosion inhibitor for carbon steel in 1.0 $\mathrm{M} \mathrm{HCl}$. We used electrochemical and weight loss methods, and surface and solution studies. Adsorption isotherms and thermodynamic parameters were also calculated and are discussed herein.

\section{Materials and methods}

\subsection{Materials}

The chemical composition of the used carbon steel (weight\%) was $0.08 \mathrm{Cr}, 0.11 \mathrm{Mo}, 0.22 \mathrm{~W}, 0.40 \mathrm{Mn}, 0.06 \mathrm{Cu}$, and the rest Fe. First, the samples were mechanically cut and prepared into five strips, each of dimensions, $20 \times 20 \times 1 \mathrm{~mm}$. The exposed area of the electrode was abraded using different grades of emery papers (grades 320-1200), polished with $\mathrm{Al}_{2} \mathrm{O}_{3}(1 \mu \mathrm{m}$ and then $0.3 \mu \mathrm{m}$ particle sizes), washed with tap water followed by distilled water, degreased with acetone, dried, and finally stored in a desiccator. The corrosive medium $(1.0 \mathrm{M} \mathrm{HCl})$ was prepared from a stock $5.0 \mathrm{M}$ $\mathrm{HCl}$ solution by dilution with bi-distilled water from a concentrated acid solution (37\%, Merck). The concentration of the stock acid solution was checked through a standard solution of $\mathrm{Na}_{2} \mathrm{CO}_{3}$.

\subsection{Chemical composition of ginger roots extract}

Ginger has been extensively studied and its chemical composition is well known. Using methanol for the solvent extraction, 
the main constituents were found to be gingerol, zingiberene, $\alpha$ farnesene, $\beta$-bisabolene, shogaol, and $\beta$-sesquiphellandrene. ${ }^{15}$

\subsection{Preparation of ginger roots extract}

The GRE was obtained directly from the powder of the dried roots. The GRE was soaked in methanol and left standing for 7 days. The solution was filtered, and distilled at $40{ }^{\circ} \mathrm{C}$ to remove the methanol from the extracts, then concentrated to dryness. Then, $1 \mathrm{~g}$ was taken from the extract and dissolved in $1000 \mathrm{~mL}$ of water to give a concentration of $1000 \mathrm{ppm}$. The corrosive medium was $1 \mathrm{M} \mathrm{HCl}$ solution. Different volumes from the stock solution of GRE (1000 ppm) were taken to prepare different concentrations by extraction with $1.0 \mathrm{M} \mathrm{HCl}$.

\subsection{Weight loss method}

The corrosion rates of carbon steel were calculated by considering the total affected sample area and immersion time. The test samples were weighed and immersed in $50 \mathrm{~mL}$ of $1.0 \mathrm{M} \mathrm{HCl}$ in the absence and presence of varying concentrations of GRE (50-200 ppm), taken in a beaker at temperatures of $25-55{ }^{\circ} \mathrm{C}$, with the temperature maintained in a thermostat water bath. The carbon steel strips were weighed and suspended in the beaker with the help of hooks. Each piece was taken out of the test solution, rinsed, and dried according to the standard method. ${ }^{16}$ The difference in weight for an exposed period of 30150 min was taken as the total weight loss. In order to get good results, the experiments were carried out in triplicate. From the average weight loss results, the corrosion rate, the percentage of inhibition efficiency (\%IE), and the degree of surface coverage $(\theta)$ were calculated using the following equations: $:^{17}$

$$
\begin{gathered}
\text { Corrosion rate }=\Delta \text { W/At } \\
(\% \mathrm{IE})=\theta \times 100=\left[\left(\mathrm{W}_{1}-\mathrm{W}_{2}\right) / \mathrm{W}_{1}\right] \times 100
\end{gathered}
$$

where $\Delta W$ is the weight loss in $\mathrm{mg}, A$ is the area of the specimen in $\mathrm{cm}^{2}, t$ is the exposure time in min, and $W_{2}$ and $W_{1}$ are the weight losses for the carbon steel sample in the presence and absence of the inhibitor.

\subsection{Electrochemical measurements}

All the electrochemical measurements were carried out using a conventional cell with three electrodes. The carbon steel was used as a working electrode, the counter electrode was a Pt wire electrode, and the reference electrode was a saturated calomel electrode (SCE). As mentioned before, the working electrode was first polished and cleaned.

The electrochemical measurements were performed using Gamry Instrument (PCI300/4) Potentiostat/Galvanostat/ZRA. This includes a Gamry framework system based on the ESA 400. Gamry applications included DC105 software for the potentiodynamic polarization measurements, EIS300 software for the electrochemical impedance spectroscopy, and EFM 140 software for the electrochemical frequency modulation measurements along with a computer for collecting data. Echem Analyst 6.03 software was used for plotting, graphically displaying, and fitting the data. Tafel polarization plots were obtained using a scan rate of $1 \mathrm{mV} \mathrm{s}{ }^{-1}$ in the potential range from -700 to $+700 \mathrm{mV}$ with respect to the open circuit potential $\left(E_{\text {ocp }}\right)$. Electrochemical impedance spectroscopy was studied at corrosion potentials, $E_{\text {corr }}$, over a frequency range of $10^{5} \mathrm{~Hz}$ to $0.2 \mathrm{~Hz}$ with a signal amplitude perturbation of $5 \mathrm{mV}$.

The electrochemical frequency modulation technique was performed by applying a potential perturbation signal with an amplitude of $10 \mathrm{mV}$ with two sine waves of 2 and $5 \mathrm{~Hz}$. The choice for the frequencies of 2 and $5 \mathrm{~Hz}$ was based on three arguments. ${ }^{18}$

\subsection{FT-IR analysis}

FT-IR analysis was carried out to determine the functional groups present in the GRE solution (200 ppm extract $+1.0 \mathrm{M}$ $\mathrm{HCl}$ ) before and after immersion of the carbon steel for $24 \mathrm{~h}$. FTIR analysis was carried out using the FT/IR-4100 type A, Serial Number B117761016.

\subsection{UV-visible spectroscopy}

The UV-visible absorption spectra of $1.0 \mathrm{M} \mathrm{HCl}$ solution containing $200 \mathrm{ppm}$ of GRE before and after immersion of the carbon steel for $24 \mathrm{~h}$ were studied.

\subsection{AFM analysis}

Atomic force microscopy (AFM) analysis is one of the major analysis methods to study a surface, and was used here for the further investigation of the formation of a protective film on the surface of the carbon steel. AFM was used to investigate the topography image of the carbon steel surface in the absence and presence of $200 \mathrm{ppm}$ of GRE before and after immersing the carbon steel in for $24 \mathrm{~h}$ (Table 1).

\section{Results and discussion}

\subsection{Weight loss measurements}

The values of the corrosion rate were plotted against different concentrations of the extract in $1.0 \mathrm{M} \mathrm{HCl}$, and the results are shown in Fig. 1. The corrosion rate of carbon steel decreased when the concentration of the extract was increased, while the magnitude of surface coverage and adsorption by the extracts on carbon steel surface increased with the concentration of the extract. From Fig. 2, it can be seen that the inhibition efficiency increases with increasing the concentration of the extract. Tables 2 and 3 show the experimental data for the weight loss $(\Delta W)$, percentage of inhibition efficiency (\%IE), corrosion rate (C.R.), and the degree of surface coverage $(\theta)$ for carbon steel in $1.0 \mathrm{M} \mathrm{HCl}$ in the absence and presence of various concentrations of GRE at different temperatures.

\subsection{Adsorption isotherms}

Adsorption isotherm values are vital to explain the mechanism of corrosion inhibition of organo-electrochemical reactions. The adsorption mode is dependent on several factors, such as the type of metal and the nature of its surface, the structure 
Table 1 Names, structural formulas, and molecular weights for of the investigated extract

\begin{tabular}{|c|c|c|c|c|}
\hline Comp. & Chemical structure & Name & $\begin{array}{l}\text { Molecular } \\
\text { weight }\end{array}$ & \%Composition \\
\hline 1 & & $\begin{array}{l}\text { (5S)-5-Hydroxy-1-(4-hydroxy-3-methoxyphenyl)- } \\
\text { decan-3-one (Gingerol) }\end{array}$ & 294.39 & 25 \\
\hline 2 & & $\begin{array}{l}(5 R)-5 \text {-[(1R)-1,5-Dimethylhex-4-en-1-yl]- } \\
\text { cyclohexa-1,3-diene (Zingiberene) }\end{array}$ & 204.357 & 9 \\
\hline 4 & & $\begin{array}{l}\text { (3E,6E)-3,7,11-trimethyldodeca-1,3,6,10-tetraene } \\
(\alpha \text {-Farnesene) }\end{array}$ & 204.357 & 11 \\
\hline 5 & & $\begin{array}{l}\text { (4E)-1-(4-Hydroxy-3-methoxyphenyl)dec-4-en-3-one } \\
\text { (Shogaol) }\end{array}$ & 276.376 & 18 \\
\hline
\end{tabular}

molecules of the extract, the nature of the corrosion medium, the temperature, and the electrochemical potential of the metal-solution interface. The degree of surface coverage $(\theta)$ of the extract must be calculated to obtain the adsorption

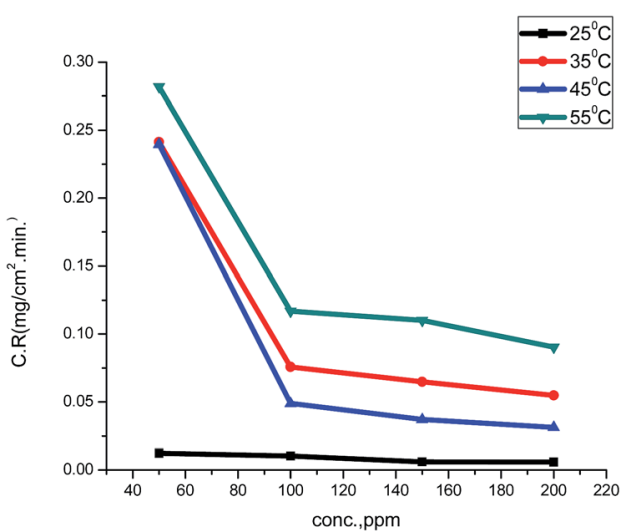

Fig. 1 Corrosion rates of various concentrations of ginger roots extract on carbon steel in $1.0 \mathrm{M} \mathrm{HCl}$ at $25-55^{\circ} \mathrm{C}$ isotherm. A number of mathematical expressions have thus been developed to take into consideration the non-ideal effects. ${ }^{19-22}$ The most frequently used isotherm is the Langmuir isotherm. In Fig. 3, according to the Langmuir isotherm,

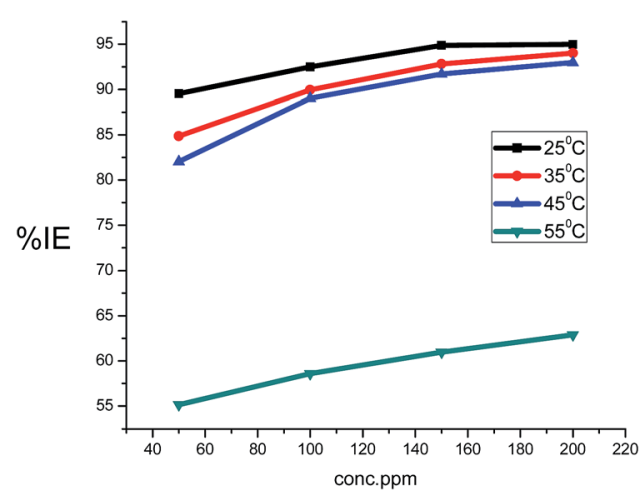

Fig. 2 Variation of the inhibition efficiency with the ginger roots extracts concentration of carbon steel in $1.0 \mathrm{M} \mathrm{HCl}$ solution. 
Table 2 Data from weight loss of carbon steel in $1.0 \mathrm{M} \mathrm{HCl}$ for various concentrations of ginger roots extracts after $90 \mathrm{~min}$, at $25^{\circ} \mathrm{C}$ and $35^{\circ} \mathrm{C}$

\begin{tabular}{|c|c|c|c|c|c|c|c|c|}
\hline \multirow[b]{2}{*}{ Conc., ppm } & \multicolumn{4}{|l|}{$25^{\circ} \mathrm{C}$} & \multicolumn{4}{|l|}{$35^{\circ} \mathrm{C}$} \\
\hline & $\begin{array}{l}\Delta W, \mathrm{mg} \\
\mathrm{cm}^{-2}\end{array}$ & $\theta$ & $\%$ IE & $\begin{array}{l}\text { C.R., } \mathrm{mg} \\
\mathrm{cm}^{-2} \min ^{-1}\end{array}$ & $\Delta W, \mathrm{mg} \mathrm{cm}^{-2}$ & $\theta$ & $\%$ IE & $\begin{array}{l}\text { C.R., } \mathrm{mg} \\
\mathrm{cm}^{-2} \mathrm{~min}^{-1}\end{array}$ \\
\hline Blank & 10.65 & & & 0.1180 & 22.265 & & & 0.2474 \\
\hline 50 & 1.11 & 0.895 & 89.5 & 0.0120 & 00.037 & 0.848 & 84.8 & 0.0375 \\
\hline 100 & 0.80 & 0.925 & 92.5 & 0.0088 & 00.076 & 0.899 & 89.9 & 0.0758 \\
\hline 150 & 0.55 & 0.948 & 94.8 & 0.0060 & 00.065 & 0.928 & 92.8 & 0.0648 \\
\hline 200 & 0.53 & 0.949 & 94.9 & 0.0059 & 00.055 & 0.940 & 94.0 & 0.0549 \\
\hline
\end{tabular}

Table 3 Data of the weight loss of carbon steel in $1 \mathrm{M} \mathrm{HCl}$ for various concentrations of ginger roots extract after 90 min at $45^{\circ} \mathrm{C}$ and $55^{\circ} \mathrm{C}$

\begin{tabular}{|c|c|c|c|c|c|c|c|c|}
\hline Conc., ppm & $\begin{array}{l}\Delta W, \mathrm{mg} \\
\mathrm{cm}^{-2}\end{array}$ & $\theta$ & $\% \mathrm{IE}$ & $\begin{array}{l}\text { C.R., } \mathrm{mg} \\
\mathrm{cm}^{-2} \mathrm{~min}^{-1}\end{array}$ & $\Delta W, \mathrm{mg} \mathrm{cm}^{-2}$ & $\theta$ & $\% \mathrm{IE}$ & $\begin{array}{l}\text { C.R., } \mathrm{mg} \\
\mathrm{cm}^{-2} \mathrm{~min}^{-1}\end{array}$ \\
\hline Blank & 40.02 & & & 1.3340 & 56.56 & & & 0.6285 \\
\hline 50 & 7.19 & 0.820 & 82.0 & 0.2397 & 25.37 & 0.551 & 55.1 & 0.2819 \\
\hline 100 & 4.39 & 0.890 & 89.0 & 0.0488 & 10.51 & 0.586 & 58.6 & 0.1168 \\
\hline
\end{tabular}

the degree of surface coverage $(\theta)$ evaluated from the weight loss method was related to the inhibitor concentration as: ${ }^{23}$

$$
C_{\text {inh. }} / \theta=1 / K_{\mathrm{ads}}+C_{\mathrm{inh}}
$$

where $C_{\text {inh. }}$ is the inhibitor concentration, $\theta$ is the fraction of the surface coverage, and $K_{\mathrm{ads}}$ is the adsorption equilibrium constant. From the intercepts and slopes of the straight lines of the Langmuir isotherm curves, the values of the equilibrium constant $\left(K_{\text {ads }}\right)$ were calculated, and the results are given in Table 4. From the obtained data, it can be seen that the values of $K_{\text {ads }}$ decrease with increasing temperature. This demonstrates that the strength of adsorption decreases with the increasing temperature and the inhibitor species are then more readily removed from the carbon steel surface. ${ }^{\mathbf{2 4 - 2 6}} K_{\text {ads }}$ can be related to the free energy of adsorption ( $\left.\Delta G_{\text {ads }}\right)$ by the following equation:

$$
K_{\mathrm{ads}}=1 / 55.5 \exp \left[-\Delta G_{\mathrm{ads}}^{\circ}\right] / R T
$$

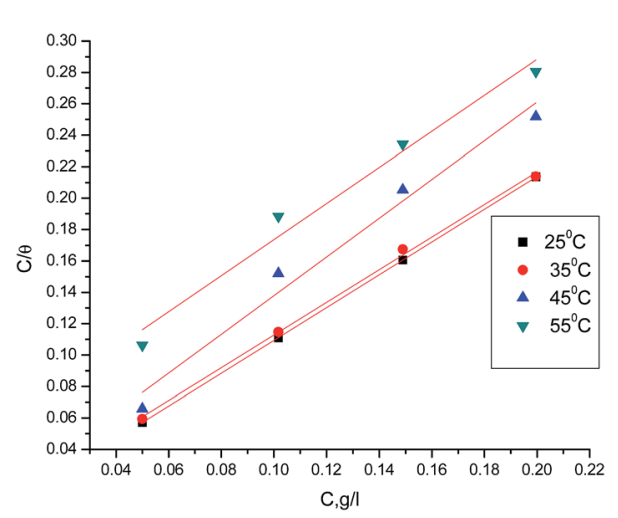

Fig. 3 Langmuir isotherm for GRE adsorption on carbon steel in $1 \mathrm{M}$ $\mathrm{HCl}$ at different temperatures.
The thermodynamic parameters for adsorption of the investigated GRE on the carbon steel surface at various temperatures were recorded and are listed in Table 4. From the data in Table 4, it was found that the negative data for $\Delta G_{\text {ads }}^{\circ}$ reflect that the adsorption of the studied extract on carbon steel in $1.0 \mathrm{M} \mathrm{HCl}$ solution was a spontaneous process. ${ }^{27}$ The obtained values of $\Delta G_{\mathrm{ads}}^{\circ}(11.93-12.22 \mathrm{~kJ})$ suggest that the adsorption of the GRE on the carbon steel surface is mainly through physical adsorption. The thermodynamic adsorption parameters, such as the enthalpy of adsorption $\Delta H_{\text {ads }}^{\circ}$ and the entropy of adsorption $\Delta S_{\text {ads }}^{\circ}$, can be deduced from the integrated version of the van't Hoff equation as expressed by ${ }^{28}$

$$
\ln K_{\mathrm{ads}}=\left(-\Delta H_{\mathrm{ads}}^{\circ} / R T\right)+\left(\Delta S_{\mathrm{ads}}^{\circ} / R\right)+\ln (1 / 55.5)
$$

The negative sign of $\Delta H_{\text {ads }}^{\circ}$ indicates that the adsorption of GRE on carbon steel surface is an exothermic process. The negative $\Delta S_{\text {ads }}^{\circ}$ values are accompanied with an exothermic adsorption process. This agrees with the expected result, whereby, when the adsorption is an exothermic process, it must

Table 4 Langmuir adsorption parameters for the adsorption of GRE on the carbon steel surface in $1.0 \mathrm{M} \mathrm{HCl}$

\begin{tabular}{lllllll}
\hline \multicolumn{5}{c}{ Langmuir } \\
\cline { 2 - 7 } Temp. & $\log K$ & Slope & $R^{2}$ & $-\Delta G_{\text {ads }}^{\circ} \mathrm{Kj}$ & $-\Delta H_{\text {ads }}^{\circ} \mathrm{Kj}$ & $-\Delta S_{\text {ads }}^{\circ} \mathrm{jK}^{-1}$ \\
\hline $25{ }^{\circ} \mathrm{C}$ & 2.33 & 1.034 & 0.99998 & 12.05 & 53.42 & 57.51 \\
$35{ }^{\circ} \mathrm{C}$ & 2.07 & 1.029 & 0.99763 & 12.15 & & \\
$45{ }^{\circ} \mathrm{C}$ & 1.83 & 1.022 & 0.96635 & 12.22 & & \\
$55^{\circ} \mathrm{C}$ & 1.43 & 1.020 & 0.98579 & 11.93 & & \\
& & & & & &
\end{tabular}


be accompanied by a decrease in the entropy change and vice versa (Fig. 4). ${ }^{29}$

\subsection{Effect of temperature on the inhibition efficiency}

From Tables 2 and 3, it can be seen that the data show that the inhibition efficiency decreases with a rise in temperature. This suggests that the GRE is adsorbed on the carbon steel surface physically. Also the data in Tables 2 and 3 reveal that the weight loss of carbon steel increases with increasing the temperature, indicating that the rate of corrosion of metal increases with increasing the temperature. The dependence of the rate of corrosion (C.R.) on the temperature can be expressed by the Arrhenius equation:

$$
\text { C.R. }=A \exp \left(-E_{\mathrm{a}}^{*} / R T\right)
$$

where $A$ is a pre-exponential factor and $E_{\mathrm{a}}^{*}$ is the apparent activation energy for the corrosion process. The Arrhenius plots in Fig. 5 show the corrosion of carbon steel in $1.0 \mathrm{M} \mathrm{HCl}$ solution with and without different concentrations of GRE. The linear regression $\left(R^{2}\right)$ is close to 1 , which indicates that the corrosion of carbon steel in 1.0 M acidic medium can be determined by using the kinetics model. Table 5 gives the data for $E_{\mathrm{a}}^{*}$, which indicates that $E_{\mathrm{a}}^{*}$ increases in the presence of GRE more than in its absence. Hence, from these data we can say that the molecules of GRE are adsorbed on the carbon steel surface physically. The entropy and enthalpy of activation $\left(\Delta H^{*}\right.$ and $\left.\Delta S^{*}\right)$ of

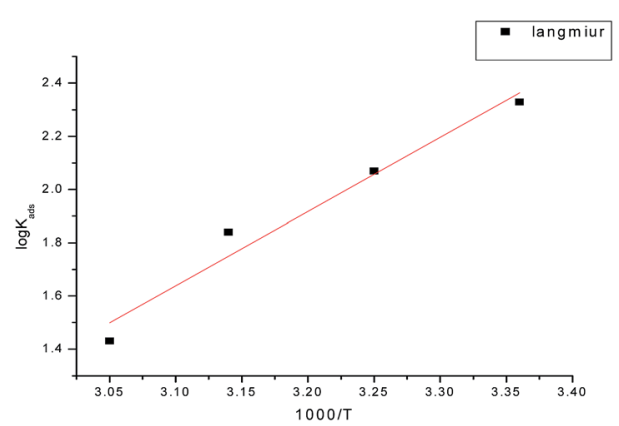

Fig. 4 Log $K_{\text {ads }} v$ s. $(1 / T)$ curves for the corrosion of carbon steel in $1 \mathrm{M}$ $\mathrm{HCl}$ in the absence and presence of different concentrations of GRE.

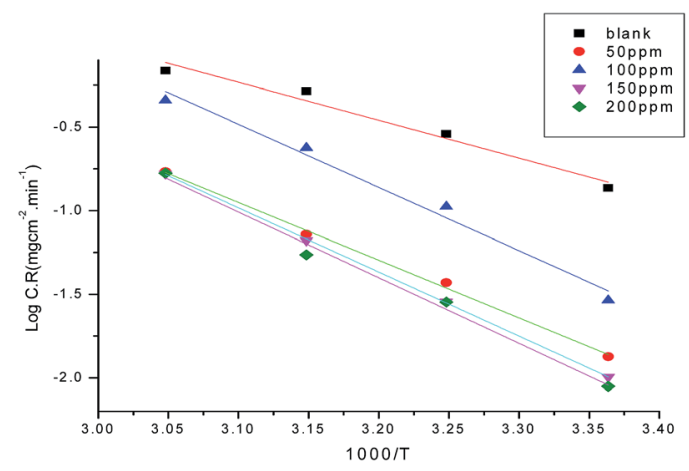

Fig. 5 Arrhenius plots (log C.R. vs. $1 / T$ ) for carbon steel in $1.0 \mathrm{M} \mathrm{HCl}$ without and with different concentrations of GRE.
Table 5 Kinetics parameters for the Arrhenius equation and transition state equation

\begin{tabular}{llll}
\hline Conc. ppm & $E_{\mathrm{a}}^{*} \mathrm{~kJ} \mathrm{~mol}^{-1}$ & $\begin{array}{l}-\Delta H^{*} \\
\mathrm{~kJ} \mathrm{~mol}^{-1}\end{array}$ & $\begin{array}{l}-\Delta S^{*} \\
\mathrm{~J} \mathrm{~mol}\end{array}$ \\
\hline Blank & 51.08 & 41.17 & 122.2 \\
50 & 66.11 & 63.89 & 65.87 \\
100 & 72.39 & 70.27 & 36.86 \\
150 & 74.00 & 71.22 & 43.32 \\
200 & 75.18 & 72.95 & 39.10
\end{tabular}

the corrosion process were calculated from the transition state theory, as given from the following equation:

$$
\text { C.R. }=(R T / N h) \exp \left(\Delta S^{*} / R\right) \exp \left(-\Delta H^{*} / R T\right)
$$

where $h$ is Planck's constant and $N$ is Avogadro's number. A plot of $\log ($ C.R./T) vs. $1 / T$ for carbon steel with different concentrations of GRE gave straight lines, as shown in Fig. 6. Here, the values of $\Delta H^{*}$ were negative. This means that the activation process is an exothermic corrosion process. The values of $\Delta S^{*}$ were also negative, but with an increase in the GRE concentration, $\Delta S^{*}$ becomes less and less negative. This indicates that the activated complex is less ordered in the presence of GRE. Table 5 reports the parameters $\left(\Delta H^{*}\right.$ and $\left.\Delta S^{*}\right)$ for the activation of carbon steel corrosion without and with various concentrations of GRE.

\subsection{Open circuit potential measurements}

The variation of the open circuit potential (OCP) of carbon steel electrodes as a function of time was measured against a saturated calomel electrode (SCE) in the absence and presence of various concentrations of the GRE, as indicated in Fig. 7. It is evident from the figure that the corrosion potential $\left(E_{\text {corr }}\right)$ of the carbon steel electrode in $1.0 \mathrm{M} \mathrm{HCl}$ solution trends first toward more negative values, giving rise to a short step. In the presence of (GRE) solutions, the open circuit potential values shifted towards more positive potentials during the immersion. This can be explained by the adsorption of (GRE) on the carbon steel

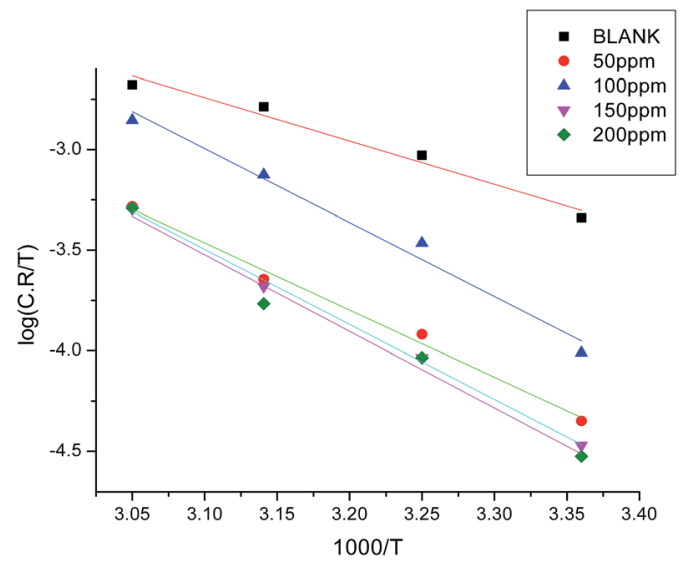

Fig. 6 Plots of log C.R./T vs. 1000/T for carbon steel in $1.0 \mathrm{M} \mathrm{HCl}$ without and with different concentrations of GRE. 


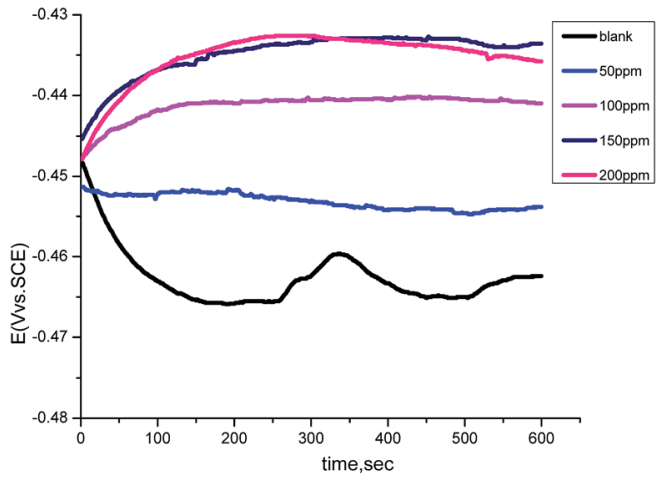

Fig. 7 Potential-time curves for carbon steel in $1.0 \mathrm{M} \mathrm{HCl}$ solution in the absence and presence of different concentrations of GRE at $25^{\circ} \mathrm{C}$

surface. After that, the values tended to stabilize, demonstrating that the adsorption and desorption of (GRE) molecules had reached a dynamic balance. ${ }^{30,31}$ This suggests that the kinetics of the anodic reaction of carbon steel in $1.0 \mathrm{M} \mathrm{HCl}$ solution was affected more strongly in the presence of the GRE.

\subsection{Potentiodynamic polarization}

A Tafel plot is a technique for determining the corrosion rate from the experimental polarization curves. The electrochemical parameters, anodic Tafel constant $\left(\beta_{\mathrm{a}}\right)$, cathodic Tafel constant $\left(\beta_{\mathrm{c}}\right)$, corrosion potential $\left(E_{\text {corr }}\right)$, corrosion current density $\left(i_{\text {corr }}\right)$, and the corresponding inhibition efficiencies for the corrosion of carbon steel in $1.0 \mathrm{M} \mathrm{HCl}$ solution without and with different concentrations (50-200 ppm) of GRE at $25^{\circ} \mathrm{C}$ are illustrated in Table 6. Fig. 8 shows the anodic and cathodic potentiodynamic polarization curves for the previous tests. The Tafel lines can be seen to be shifted to more negative and more positive potentials with respect to the blank curve when increasing the concentration of the investigated extract. These observations indicate that the GRE is a mixed-type inhibitor for the corrosion of carbon steel in $1.0 \mathrm{M} \mathrm{HCl} .^{32,33}$ From Table 6 the values of $E_{\text {corr }}$ can be seen to be slightly shifted to more positive potentials when increasing the concentration of GRE. These results suggest that this extract acts as a mixed-type inhibitor that acts predominately on the anodic dissolution of the metal. ${ }^{34}$ These results demonstrate that an increase in extract concentration leads to a decrease in the corrosion current density $\left(I_{\text {corr }}\right)$, as indicated in the potentiodynamic polarization curves, which

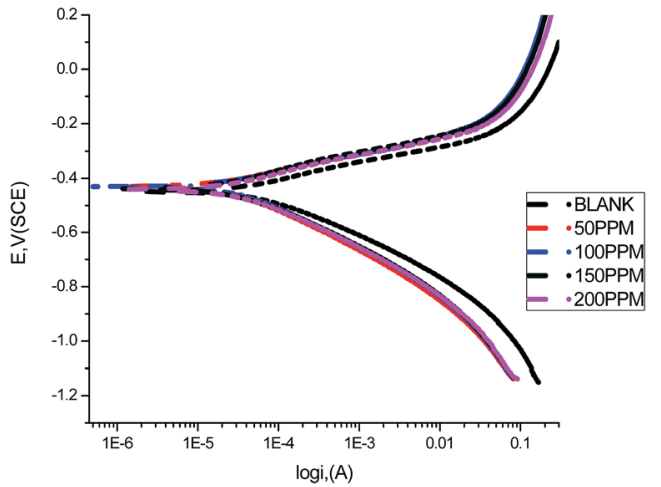

Fig. 8 Anodic and cathodic polarization curves for carbon steel in $1.0 \mathrm{M} \mathrm{HCl}$ in the absence and presence of different concentrations of GRE at $25^{\circ} \mathrm{C}$.

can be explained by the adsorption of organic compounds, such as heteroatoms, at the carbon steel surface. The Tafel slopes $\left(\beta_{\mathrm{a}}\right.$ and $\beta_{\mathrm{c}}$ ) are approximately constant, indicating that the retardation of the two reactions (cathodic hydrogen reduction and anodic metal dissolution) were affected without changing the dissolution mechanism..$^{35-37}$ The degree of surface coverage $(\theta)$ and the inhibition efficiency $(\eta)$ were calculated using eqn (8):

$$
\% \eta=\theta \times 100=\left[1-\left(I / I^{\circ}\right)\right] \times 100
$$

where $I^{\circ}$ and $I$ are the current densities in the absence and presence of the extract, respectively.

\subsection{Electrochemical impedance spectroscopy}

From the EIS technique, we can gain information on the resistive and capacitive behavior at the interface and this made it possible to evaluate the performance of the test compound as a corrosion inhibitor. ${ }^{38-40}$ The interface of the metal surface and aqueous electrolyte is a complex environment consisting of a line of positive and negatively charged ions. Also it can contains a coating or film formation on surfaces, capacitance due to an electrical double layer $\left(C_{\mathrm{dl}}\right)$, charge transfer resistance $\left(R_{\mathrm{ct}}\right)$, solution resistance $\left(R_{\mathrm{S}}\right)$,and various impedances due to the diffusion of ions, the movement of charge in or away from the metal surface, and from the adsorption of cations and anions. Table 7 shows the data for the impedance of carbon steel in 1.0 $\mathrm{M} \mathrm{HCl}$ without and with various concentrations of GRE.

Table 6 Potentiodynamic polarization parameters for carbon steel corrosion in $1.0 \mathrm{M} \mathrm{HCl}$ in the absence and presence of different concentrations of GRE at $25^{\circ} \mathrm{C}$

\begin{tabular}{|c|c|c|c|c|c|c|c|c|}
\hline Conc., ppm & $\begin{array}{l}-E_{\text {corr }}, \mathrm{mV} \\
\text { vs. SCE }\end{array}$ & $R_{\mathrm{P}, \mathrm{ohm}}$ & $i_{\text {corr }}, \mu \mathrm{A} \mathrm{cm}{ }^{-2}$ & $\beta_{\mathrm{a}}, \mathrm{mV} \mathrm{dec}{ }^{-1}$ & $-\beta_{\mathrm{c}}, \mathrm{mV} \mathrm{dec}{ }^{-1}$ & $\theta$ & $\%$ IE & mpy \\
\hline Blank & 448 & 3.10 & 464.0 & 123.0 & 195.2 & - & - & 212.1 \\
\hline 100 & 437 & 5.72 & 42.9 & 113.5 & 195.6 & 0.908 & 90.8 & 19.6 \\
\hline 150 & 430 & 6.08 & 42.0 & 91.1 & 198.1 & 0.910 & 91.0 & 19.21 \\
\hline 200 & 431 & 6.40 & 35.9 & 94.7 & 187.1 & 0.923 & 92.3 & 16.41 \\
\hline
\end{tabular}


Table 7 EIS parameters for the corrosion of carbon steel in $1.0 \mathrm{M} \mathrm{HCl}$ in the absence and presence of different concentrations of $\mathrm{GRE}$ at $25^{\circ} \mathrm{C}$

\begin{tabular}{|c|c|c|c|c|c|c|c|}
\hline Conc., ppm & $R_{\mathrm{ct}}, \Omega \mathrm{cm}^{-2}$ & $R_{\mathrm{S}}, \Omega \mathrm{cm}^{-2}$ & $Y_{0} \times 10^{6}, \mathrm{ohm}^{-1} \mathrm{Sn} \mathrm{cm}^{-2}$ & $n$ & $C_{\mathrm{dl}} \times 10^{-2}, \mu \mathrm{F} \mathrm{cm} \mathrm{cm}^{-2}$ & $\theta$ & $\% \mathrm{IE}$ \\
\hline Blank & $83.81 \pm 0.527$ & $1.189 \pm 35.2 \times 10^{-3}$ & $686.8 \pm 6.87$ & $0.859 \pm 0.0049$ & 2.840 & - & - \\
\hline 50 & $730.8 \pm 9.172$ & $1.796 \pm 16.1 \times 10^{-3}$ & $306.2 \pm 2.29$ & $0.737 \pm 0.002$ & 1.794 & 0.885 & 88.5 \\
\hline 150 & $761.1 \pm 8.87$ & $1.963 \pm 17.44 \times 10^{-3}$ & $242.0 \pm 3.44$ & $0.752 .0 \pm 0.002$ & 1.390 & 0.890 & 89.0 \\
\hline 200 & $891.50 \pm 11.84$ & $2.074 \pm 17.78 \times 10^{-3}$ & $290 \pm 3.94$ & $0.744 \pm 0.002$ & 1.820 & 0.906 & 90.6 \\
\hline
\end{tabular}

Impedance diagrams (Nyquist and Bode plots) obtained for carbon steel in the presence of various concentrations of GRE are depicted in Fig. 10 and 11. The diameter of the semicircle and hence charge transfer resistance $R_{\mathrm{ct}}$ of the corrosion reaction increase with the increasing extract concentration. ${ }^{\mathbf{4 1 , 4 2}}$ This was attributed to the high resistance shown by the adsorbed extract components at the metal-solution interface. ${ }^{43}$ The decrease in $C_{\mathrm{dl}}$ compared with that in the blank solution (without different concentrations of the extract). This results from a decrease in the local dielectric constant and/or an increase in the thickness of the electrical double layer. This happens when the extract molecules are adsorbed at the metalsolution interface. ${ }^{\mathbf{4 4}}$ The obtained impedance diagrams have an almost semicircular appearance, indicating a charge transfer process, which mainly controls the corrosion of carbon steel. ${ }^{45}$ The EIS data were simulated using the equivalent circuit shown in Fig. 9. This circuit includes constant phase elements (CPEs) in place of capacitors to represent various types of non-

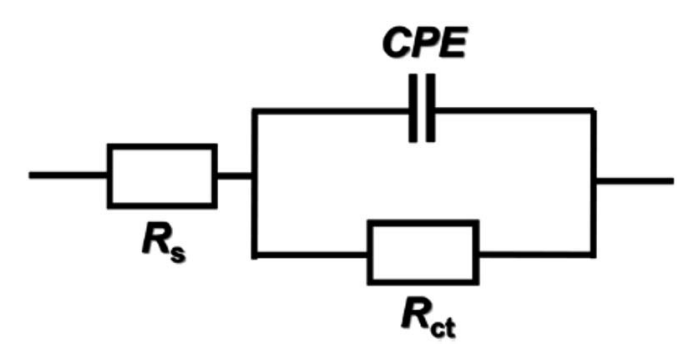

Fig. 9 Equivalent circuit proposed to fit the EIS experimental data.

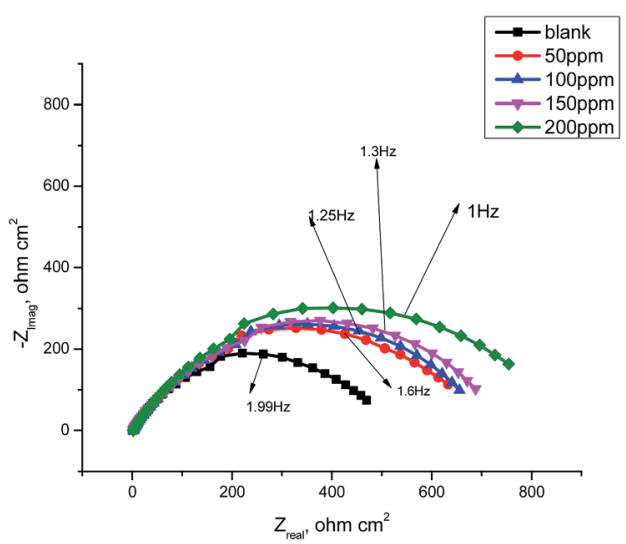

Fig. 10 Nyquist plots for the corrosion of carbon steel in $1.0 \mathrm{M} \mathrm{HCl}$ in the absence and presence of different concentrations of GRE at $25^{\circ} \mathrm{C}$. homogeneities typical of corroding electrodes, such as surface roughness, insufficient polishing, grain boundaries, and surface impurities. ${ }^{46}$ The impedance of this element is frequency dependent, and can be mathematically expressed using two parameters: $Y_{\mathrm{o}}$ and $n$, by: ${ }^{47}$

$$
Z_{\mathrm{CPE}}=Y_{\mathrm{o}}^{-1}(j \omega)^{n-1}
$$

where $Y_{\mathrm{O}}$ is the magnitude of $\mathrm{CPE}, j^{2}=-1$ is an imaginary number, and $\omega$ is the sine wave modulation angular frequency ( $\omega=2 \pi f$, where $f$ is the ac frequency). In actual experimental conditions, the values of $n$ are between 0 and 1 due to the influence of different factors, such as the electrode roughness, surface heterogeneity, and the dielectric constant. ${ }^{48}$ The double layer capacitance, $C_{\mathrm{dl}}$, was calculated from eqn (10): ${ }^{\mathbf{9}}$

$$
C_{\mathrm{dl}}=Y_{0} \omega^{n-1} / \sin [n(\pi / 2)]
$$

The degree of surface coverage $(\theta)$ and the inhibition efficiency $(\% \eta)$ were calculated from the EIS data using eqn (11):

$$
\% \eta=\theta \times 100=\left[1-\left(R_{\mathrm{p}}^{\circ} / R_{\mathrm{p}}\right)\right] \times 100
$$

where $R_{\mathrm{ct}}$ and $R_{\mathrm{s}}$ are the charge transfer resistances with and without the inhibitors, respectively. $\theta$ and $\% \eta$ are also listed in Table 7.

\subsection{Electrochemical frequency modulation measurements}

The electrochemical frequency modulation (EFM) technique has many features, such as, it is a rapid test, directly gives values

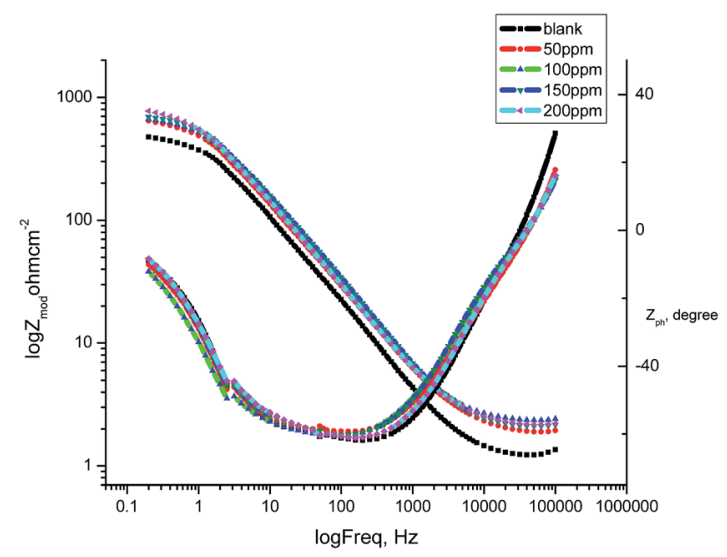

Fig. 11 Bode plots for the corrosion of carbon steel in $1 \mathrm{M} \mathrm{HCl}$ in the absence and presence of different concentrations of GRE at $25^{\circ} \mathrm{C}$. 
of the corrosion current without a prior knowledge of Tafel constants needed, and is a non-destructive technique. ${ }^{50}$ Like EIS, it is a small signal ac technique. Unlike EIS, however, two sine waves (at different frequencies) are applied to the cell simultaneously. Because the current is a non-linear function of potential excitation, the current response contains not only the input frequencies, but also contains frequency components, which are the sum, difference, and multiples of the two input frequencies. The two frequencies may not be chosen at random. They must both be small, integer multiples of a base frequency that determines the length of the experiment. Table 8 shows the corrosion kinetic parameters, such as inhibition efficiency, corrosion current density $\left(\mu \mathrm{A} \mathrm{cm}{ }^{-2}\right)$, Tafel constants $\left(\beta_{\mathrm{a}}, \beta_{\mathrm{c}}\right)$, and causality factors (CF-2, CF-3) at different concentrations of extract in $1.0 \mathrm{M} \mathrm{HCl}$ at $25^{\circ} \mathrm{C}$. The inhibition efficiency, \% IE and the degree of surface coverage $(\theta)$ of GRE were calculated using eqn (12):

$$
\% \mathrm{IE}=\theta \times 100=\left[1-\left(i_{\text {corr }} / i_{\text {corr }}^{\circ}\right)\right] \times 100
$$

where $i_{\text {corr }}^{\circ}$ and $i_{\text {corr }}$ are the corrosion current density in the absence and presence of GRE. From this table, the corrosion current densities decreases and the inhibition efficiencies increase when increasing the concentration of the extract. The great strength of the EFM is the causality factor, which serves as an internal check on the validity of the EFM measurement. ${ }^{51}$ The values of causality factors given in Table 8 indicate that the measured data are of good quality. The standard values for CF-2 and CF-3 were 2.0 and 3.0, respectively. If the causality factors differ significantly from the theoretical values of 2.0 and 3.0, then it can be deduced that the measurements are influenced by noise. Whereas, if the causality factors are approximately equal to the predicted values of 2.0 and 3.0, it indicates that there is a causal relationship between the perturbation signal and the response signal. Then the data is assumed to be reliable. ${ }^{52}$ Fig. 12 shows the corresponding current response in the intermodulation spectrum.

\subsection{Atomic force microscopy}

Atomic force microscopy (AFM) or scanning force microscopy (SFM) is a very high-resolution type of scanning probe microscopy, with demonstrated resolution in the order of fractions of a nanometer, more than 1000 times better than the optical diffraction limit. ${ }^{53,54}$ The morphology of the surface of carbon steel after immersion for $24 \mathrm{~h}$ in $1.0 \mathrm{M} \mathrm{HCl}$ solution without and with $200 \mathrm{ppm}$ of GRE was examined in the light of an atomic force microscope. The three-dimensional (3D) AFM morphology and the AFM cross-sectional profile for polished carbon steel surface (reference sample), carbon steel surface immersed in 1.0 M HCl (blank sample), and the carbon steel surface immersed in $1.0 \mathrm{M} \mathrm{HCl}$ containing $200 \mathrm{ppm}$ GRE are shown in Fig. 13-15. Table 9 is a summary of the $S_{\mathrm{q}}, S_{\mathrm{a}}$, and $P-V$ values for the carbon steel surface immersed in different environments. Whereas, $S_{\mathrm{q}}$ is root-mean-square roughness (the average of the measured height deviations taken within the evaluation length and measured from the mean line), $S_{\mathrm{a}}$ is the average roughness (the average deviation of all points' roughness profile from a mean line over the evaluation length), and the $P-V$ value is the maximum peak-to-valley height values (largest single peak-tovalley height in five adjoining sampling heights). Fig. 13 displays the surface topography of the un-corroded metal surface. The value of $S_{\mathrm{q}}, S_{\mathrm{a}}$, and the $P-V$ height for the polished carbon steel surface (reference sample) are 24.792, 20.628, and $137.07 \mathrm{~nm}$, respectively. The slight roughness observed on the polished carbon steel surface was due to atmospheric corrosion. Fig. 14 displays the corroded metal surface in the absence of the GRE immersed in $1.0 \mathrm{M} \mathrm{HCl}$. The $S_{\mathrm{q}}, S_{\mathrm{a}}$, and $P-V$ height values for the carbon steel surface are 590.07, 497.92, and $3932 \mathrm{~nm}$, respectively. These data suggest that the carbon steel surface immersed in $1.0 \mathrm{M} \mathrm{HCl}$ has a greater surface roughness than the polished metal surface. Fig. 15 displays the steel surface after immersion in $1.0 \mathrm{M} \mathrm{HCl}$ containing $200 \mathrm{ppm}$ of GRE. The $S_{\mathrm{q}}, S_{\mathrm{a}}$, and $P-V$ height values for the carbon steel surface are $558.25,430.5$, and $3592.7 \mathrm{~nm}$, respectively. The $S_{\mathrm{q}}, S_{\mathrm{a}}$, and $P-V$ height values are considerably less in the inhibited environment compared to the uninhibited environment. These parameters confirm that the surface is smoother. The smoothness of the surface is due to the formation of a compact protective film of $\mathrm{Fe}^{2+}$-GRE complex on the metal surface; thereby, inhibiting the corrosion of carbon steel..$^{55,56}$

\subsection{Analysis of the FT-IR spectra}

To identify the functional groups present in GRE, we used FT-IR analysis. The FT-IR spectra of the extract and the corrosion products are presented in Fig. 16. The results obtained show that corrosion inhibition takes place through an adsorption process. The spectrum of the $200 \mathrm{ppm}$ of GRE in $1.0 \mathrm{M} \mathrm{HCl}$. Fig. 16 shows that broad peaks appeared at 3396, 1628, 1422 and $2296 \mathrm{~cm}^{-1}$, which correspond to the $\mathrm{O}-\mathrm{H}, \mathrm{C}=\mathrm{O}, \mathrm{C}=\mathrm{C}$ and aliphatic $\mathrm{C}-\mathrm{H}$ stretching vibration frequencies, respectively. Thus, GRE was characterized by IR spectroscopy. ${ }^{57}$ There was a shift in the spectra of the extract when carbon steel was

Table 8 Electrochemical kinetic parameters obtained by EFM technique for metal in1 $\mathrm{M} \mathrm{HCl}$ solutions with GRE at $25^{\circ} \mathrm{C}$

\begin{tabular}{|c|c|c|c|c|c|c|c|c|}
\hline Conc., ppm & $i_{\text {corr }}, \mu \mathrm{A} \mathrm{cm}{ }^{-2}$ & $\beta_{\mathrm{a}}, \mathrm{mV} \mathrm{dec}{ }^{-1}$ & $-\beta_{\mathrm{c}}, \mathrm{mV} \mathrm{dec}{ }^{-1}$ & $\mathrm{CF}-2$ & CF-3 & $\theta$ & $\% \mathrm{IE}$ & mpy \\
\hline Blank & 585.5 & 94.37 & 137.2 & 1.99 & 2.79 & & & 267.5 \\
\hline 50 & 48.46 & 109.1 & 201.6 & 2.02 & 2.83 & 0.917 & 91.7 & 22.15 \\
\hline 150 & 36.59 & 100 & 175.8 & 3.8 & 2.19 & 0.9375 & 93.75 & 16.72 \\
\hline 200 & 36.26 & 89.04 & 160.2 & 1.78 & 2.40 & 0.938 & 93.8 & 16.57 \\
\hline
\end{tabular}



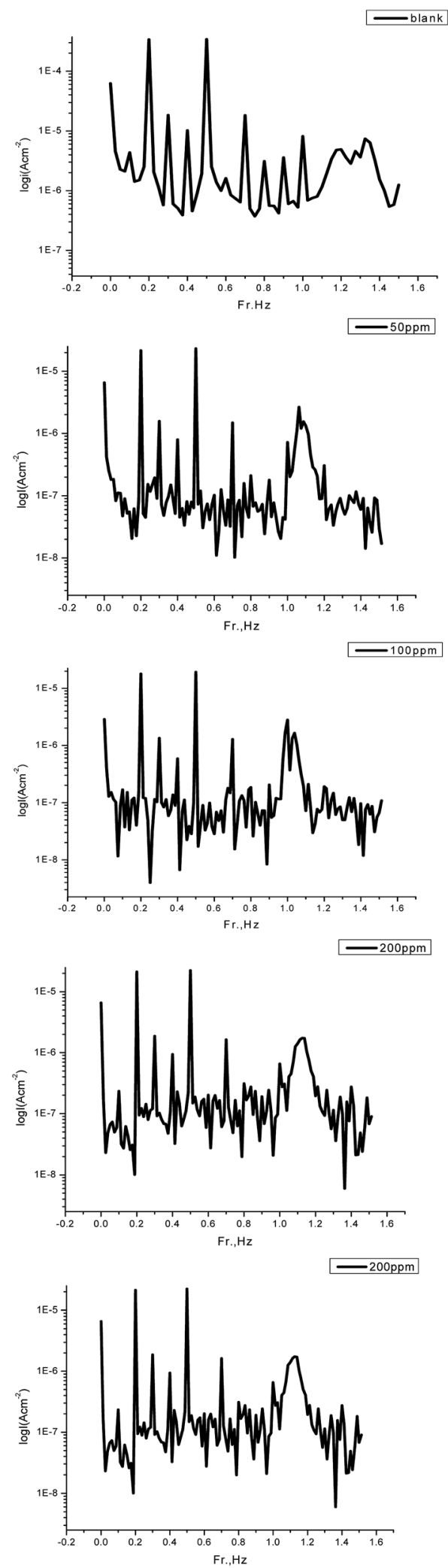

Fig. 12 Intermodulation spectra for steel in $1.0 \mathrm{M} \mathrm{HCl}$ in the absence and presence of various concentrations of GRE in $1.0 \mathrm{M} \mathrm{HCl}$ at $25^{\circ} \mathrm{C}$.

immersed in it to form a corrosion product, as shown in Fig. 17. This shows that there is an interaction between the extract and the carbon steel substrate, which resulted in inhibition. The shifts in the spectra are considered to be a result of the interaction between the extracts and carbon steel through the functional groups presents in them. So, it can be affirmed that the functional group has coordinated with $\mathrm{Fe}^{2+}$ formed on the metal surface, resulting in the formation of an $\mathrm{Fe}^{2+}$ extract complex on the metal surface, which promotes the inhibition of the metal sample.

\subsection{UV-visible analysis}

Visible absorption spectra obtained from $1.0 \mathrm{M} \mathrm{HCl}$ solution containing $200 \mathrm{ppm}$ GRE before and after the carbon steel immersion are shown in Fig. 18. The spectra confirmed the possibility of the formation of an inhibitor-Fe complex. The electronic absorption spectra of GRE before immersion have an absorption maximum at $215 \mathrm{~nm}$, which can be attributed to $\pi-$ $\pi^{*}$ and $\mathrm{n}$-transitions. After $24 \mathrm{~h}$ immersion of the carbon steel, the change in the position of the absorption maximum or the change in the absorbance values indicates the complex formation between two species in solution. Furthermore, there is no change in the shape of the absorption spectra. These experimental findings provide evidence for the formation of a complex between $\mathrm{Fe}^{2+}$ and GRE and confirm the inhibition of steel from corrosion..$^{58,59}$

\subsection{Mechanism of inhibition}

For the corrosion of carbon steel in $\mathrm{HCl}$ solution, the anodic (metal dissolution) and cathodic (hydrogen evolution) half reactions are: ${ }^{60-63}$

$$
\begin{gathered}
\mathrm{Fe} \rightarrow \mathrm{Fe}^{2+}+2 \mathrm{e}^{-} \\
2 \mathrm{H}^{+}+2 \mathrm{e}^{-} \rightarrow \mathrm{H}_{2} \uparrow
\end{gathered}
$$

The overall corrosion reaction equation is:

$$
\mathrm{Fe}+2 \mathrm{H}^{+} \rightarrow \mathrm{Fe}^{2+}+\mathrm{H}_{2} \uparrow
$$

The dissolution of iron was demonstrated according to the following equations: ${ }^{64}$

$$
\begin{gathered}
\mathrm{Fe}+\mathrm{Cl}^{-} \rightarrow\left(\mathrm{FeCl}^{-}\right)_{\mathrm{ads}} \\
\left(\mathrm{FeCl}^{-}\right)_{\mathrm{ads}} \rightarrow(\mathrm{FeCl})_{\mathrm{ads}}+\mathrm{e}^{-} \\
(\mathrm{FeCl})_{\mathrm{ads}} \rightarrow\left(\mathrm{FeCl}^{+}\right)+\mathrm{e}^{-} \\
\left(\mathrm{FeCl}^{+}\right) \rightarrow \mathrm{Fe}^{2+}+\mathrm{Cl}^{-}
\end{gathered}
$$

The hydrogen production occurs via two successive steps: to begin with, the initial discharge of hydrogen ions to adsorbed monoatomic hydrogen: ${ }^{65}$

$$
\mathrm{H}^{+}+\mathrm{e} \rightarrow \mathrm{H}^{0}
$$


Table 9 Morphology data of the surface of carbon steel after immersion for $24 \mathrm{~h}$ in $1.0 \mathrm{M} \mathrm{HCl}$ solution without and with 200 ppm of GRE was examined in the light of an atomic force microscope

\begin{tabular}{|c|c|c|c|}
\hline Samples & $S_{\mathrm{q}}(\mathrm{nm})$ & $S_{\mathrm{a}}(\mathrm{nm})$ & $\begin{array}{l}\text { Maximum peak-to-valley } \\
\text { height }(\mathrm{nm})\end{array}$ \\
\hline 1 - Polished carbon steel & 24.792 & 20.628 & 137.07 \\
\hline 3 - Carbon steel immersed in $1 \mathrm{M} \mathrm{HCl}+200 \mathrm{ppm}$ GRE & 558.25 & 430.52 & 3592.7 \\
\hline
\end{tabular}
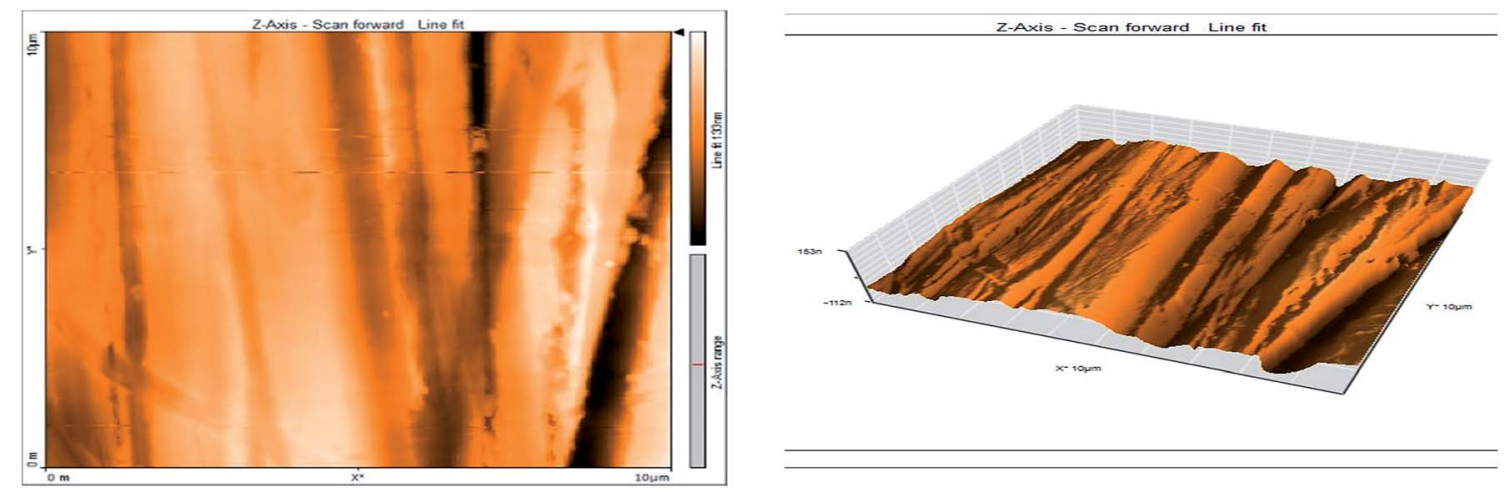

Fig. 13 Surface of polished carbon steel electrode as viewed by atomic force microscopy.

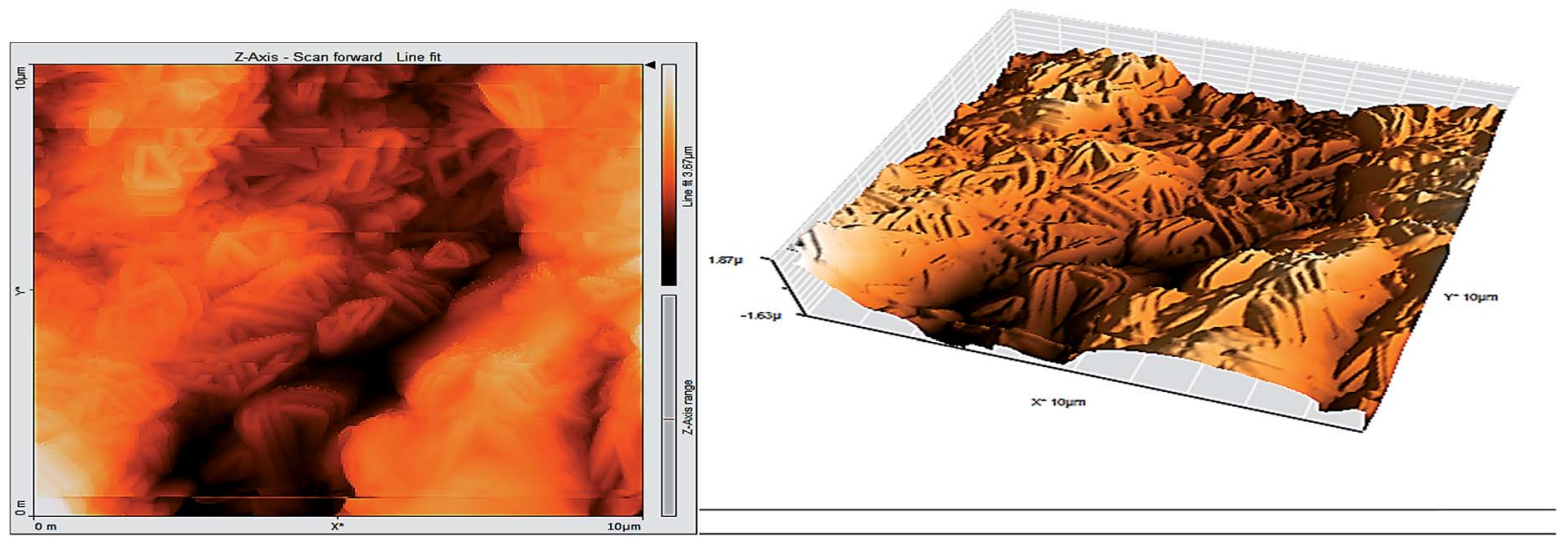

Fig. 14 Surface of steel electrode as viewed by atomic force microscopy after $24 \mathrm{~h}$ immersion in $1.0 \mathrm{M} \mathrm{HCl}$.

After that, the chemical or electrochemical recombination of monoatomic hydrogen to molecular hydrogen:

$$
\begin{gathered}
2 \mathrm{H}^{0} \rightarrow \mathrm{H}_{2} \uparrow \\
\mathrm{H}^{+}+\mathrm{H}^{0}+\mathrm{e} \rightarrow \mathrm{H}_{2} \uparrow
\end{gathered}
$$

In $\mathrm{HCl}$ solution, transition of the metal-solution interface was attributed to the adsorption of the inhibitor molecules at the metal-solution interface, forming a protective film. The rate of adsorption is usually rapid, and the reactive metal surface is shielded from the $\mathrm{HCl}$ solution solutions. ${ }^{66}$ The adsorption of the extract components depends on the nature and charged surface of the metal, its chemical structure, its molecular structure, its molecular size, and the distribution of charge over the whole extract molecule. The adsorption process can occur through the replacement of solvent molecules from the metal surface by ions and from molecules accumulated near the metal-solution interface. Ions can accumulate at the metalsolution interface in excess of those required to balance the charge on the metal at the operating potential. The exact nature of the interaction between a metal surface and an aromatic molecule depends on the relative coordinating strength toward the given metal of the particular groups present. ${ }^{67}$ Generally, two modes of adsorption were considered. In one mode, the neutral component molecules of the GRE can be adsorbed on the surface of the carbon steel through the chemisorption mechanism, involving the displacement of water molecules from the carbon steel surface and the sharing of electrons 

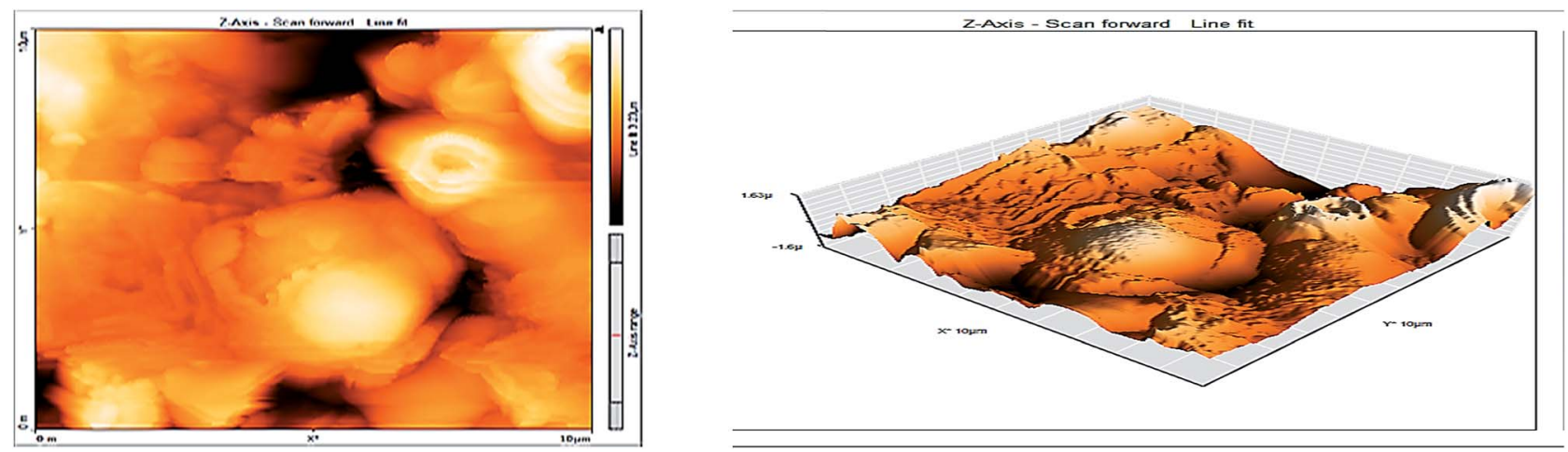

Fig. 15 Surface of steel electrode as viewed by atomic force microscopy after $24 \mathrm{~h}$ immersion in $1.0 \mathrm{M} \mathrm{HCl}$ and $200 \mathrm{ppm}$ of GRE.

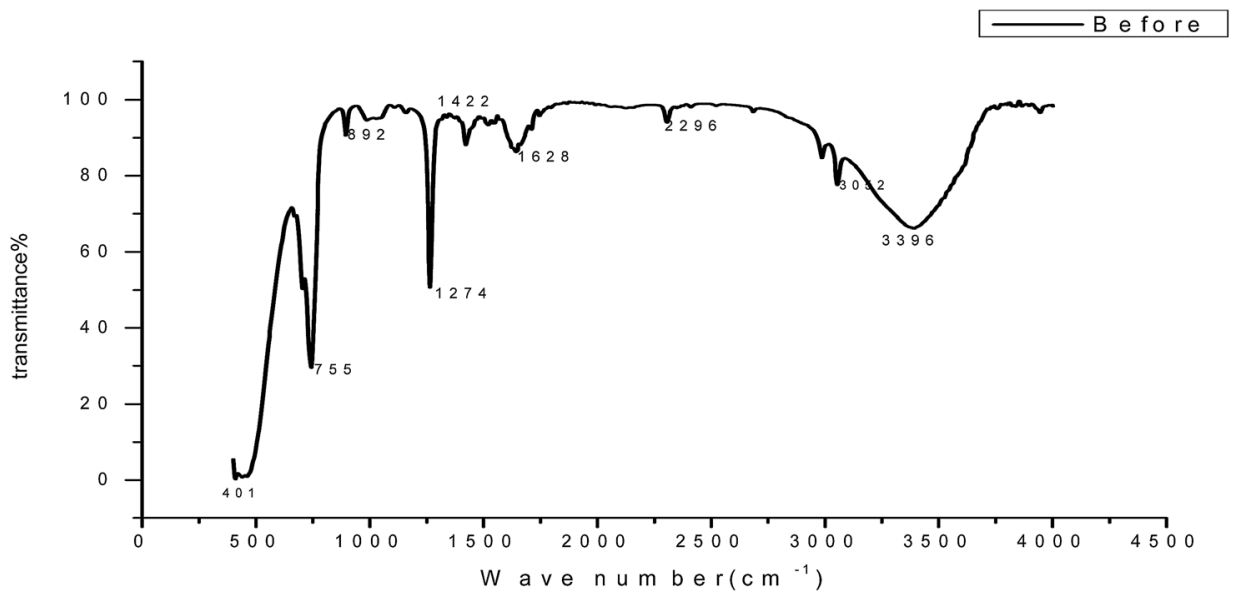

Fig. 16 FT-IR spectrum of GRE before adsorption on a carbon steel surface.

between the heteroatoms and iron. The inhibitor molecules can also adsorb on the carbon steel surface based on donoracceptor interactions between $\pi$-electrons of the aromatic/ heterocyclic ring and the vacant d-orbitals of the surface iron. In the other mode, since it is well known that the steel surface bears the positive charge in acidic solutions, ${ }^{67}$ it is difficult for the protonated component molecules extract to approach the positively charged carbon steel surface $\left(\mathrm{H}_{3} \mathrm{O}\right.$-metal interface) because of electrostatic repulsion. Since chloride ions have a smaller degree of hydration, they could bring excess negative charges in the vicinity of the interface and favor more adsorption of the positively charged inhibitor molecules and the negatively charged metal surface.

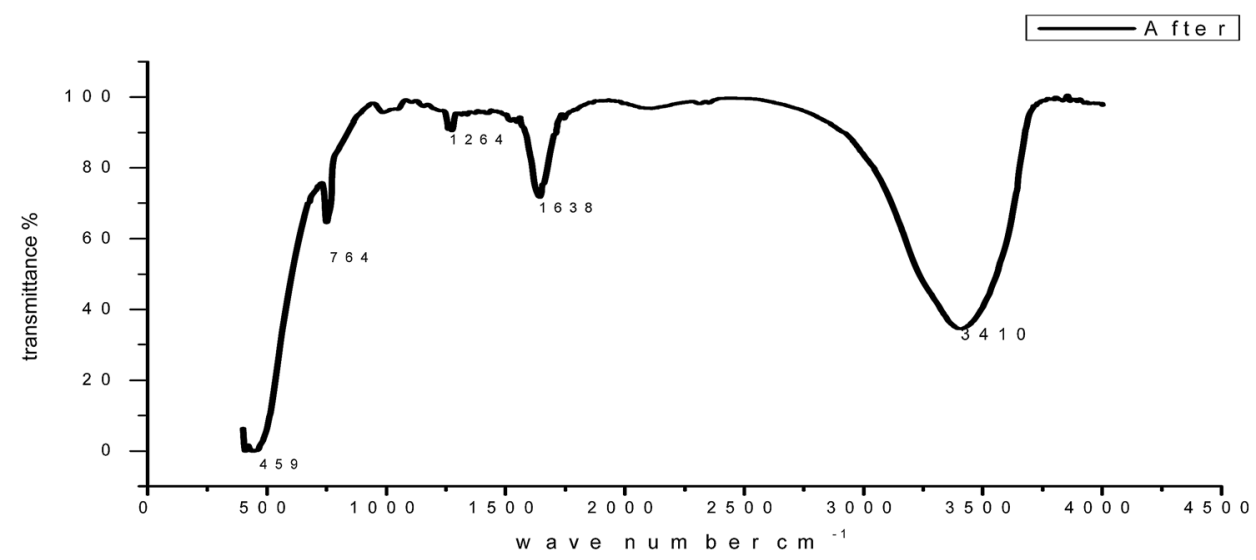

Fig. 17 FT-IR spectrum of GRE after adsorption on a carbon steel surface. 

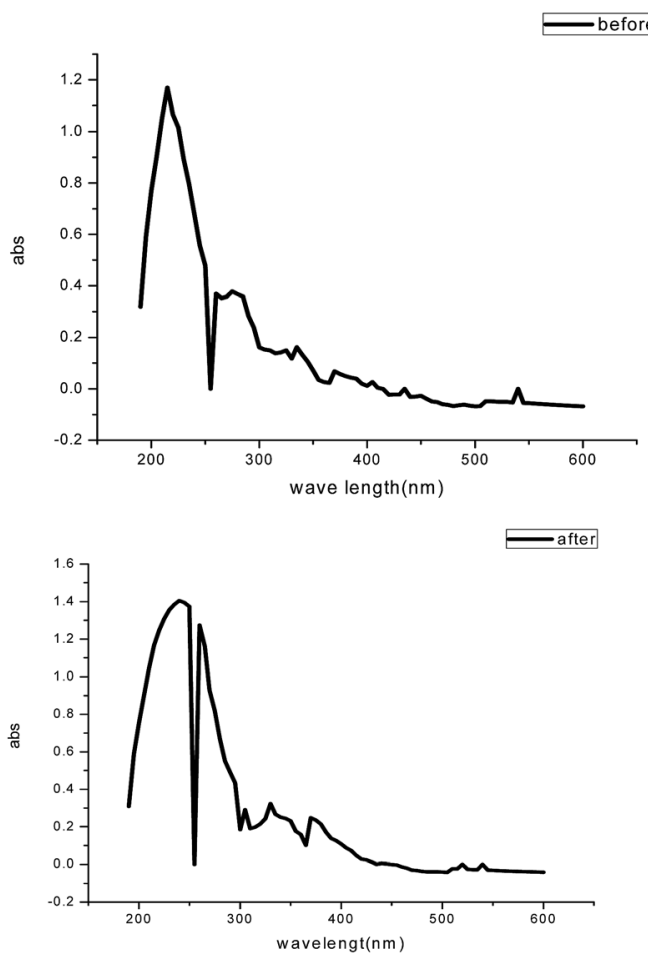

Fig. $18 U V$-visible spectra of the solution from $1.0 \mathrm{M} \mathrm{HCl}$ containing 200 ppm GRE before and after $24 \mathrm{~h}$ of carbon steel immersion.

\section{Conclusions}

The results obtained show that GRE is a good corrosion inhibitor for carbon steel under acidic conditions. An excellent agreement between the inhibition efficiencies calculated using different techniques was obtained. The data obtained from the wt. loss showed that the inhibiting action increased with the increase in extract concentration and decreased with higher temperature. The adsorption of the GRE onto the steel surface was characterized by a decrease in the cathodic and anodic current densities observed in the potentiodynamic polarization curves carried out in the presence of GRE. The adsorption behavior of the GRE is consistent with Langmuir adsorption isotherm. GRE was adsorbed on the carbon steel surface following a physisorption mechanism. The results of the polarization indicated that GRE is of a mixed type. A good agreement was obtained between all the investigated electrochemical techniques and the other techniques.

\section{References}

1 M. Yadav, S. Kumar, R. R. Sinha, I. bahdur and E. E. Ebenso, J. Mol. Liq., 2015, 211, 135-145.

2 M. Tourabi, K. Nohair, M. Traisnel, C. Jama and F. Bentiss, Corros. Sci., 2013, 75, 123-133.

3 A. Kosari, M. Momeni, R. Parvizi, M. Zakeri, M. H. Moayed, A. Davoodi and H. Eshghi, Corros. Sci., 2011, 53, 3058-3067. 4 H. Keles, Mater. Chem. Phys., 2011, 130, 1317-1324.
5 A. O. Yuce, R. Solmaz and G. Kardas, Mater. Chem. Phys., 2012, 131, 615-620.

6 M. Gopiraman, N. Selvakumaran, D. Kesavan and R. Karvembu, Prog. Org. Coat., 2012, 73, 104-111.

7 D. K. Yadav, M. A. Quraishi and B. maiti, Corros. Sci., 2012, 55, 254-266.

8 M. Librini, F. Robert, A. Lecante and C. Roos, Corros. Sci., 2011, 53, 687-695.

9 A. S. Fouda, S. Etaiw and W. Elnaggar, Int. J. Electrochem. Sci., 2014, 9, 4866-4883.

10 L. Li, X. Zhang, j. Lei, J. He, S. Zhang and F. Pan, Corros. Sci., 2012, 63, 82.

11 N. Odewunmi, S. Umoren and Z. Gasem, J. Ind. Eng. Chem., 2015, 21, 239.

12 M. Mageed, A. Sultan and H. Al- Sahlanee, J. Chem. Pharm. Res., 2013, 5, 1297.

13 L. Atia, R. Salghi, L. Bammou, L. h. Bazzi, B. Hammouti and L. Bazzi, Acta Metall. Sin., 2012, 25, 10-18.

14 C. Sells, O. Benali, B. Tabti, L. Larabi and Y. Harek, J. Mater. Environ. Sci., 2012, 3, 206-219.

15 H. A. Hasan, A. M. Rasheed Raauf, B. M. Abd Razik and B. A. Rasool Hassan, Pharm. Anal. Acta, 2012, 3(9), 1000184-1100085.

16 ASTM, AST G 31-72, Standard Recommended Practice for the Laboratory Immersion Corrosion Testing of Metals, American Society for Testing and Materials, Philadelphia, PA, USA, 1990.

17 E. Barsoukov and J. R. Macdonald, Impedance Spectroscopy, Theory, Experiment and Applications, Wiley Interscience publications, New York, 2nd edn, 2005.

18 R. W. Bosch, J. Hubrecht, W. F. Bogaerts and B. C. Syrett, Corrosion, 2011, 57, 60-70.

19 Z. M. Hadi and J. Al-Sawaad, J. Mater. Environ. Sci., 2011, 2(2), 128-147.

20 P. Roy, P. Karfa, U. Adhikari and D. Sukul, Corros. Sci., 2014, 88, 246-3253.

21 A. Amin, K. F. Khaled, Q. Mohsen and A. Arida, Corros. Sci., 2010, 52, 1684-1695.

22 S. A. Umoren, O. Ogbobe, I. O. Igwe and E. E. Ebenso, Corros. Sci., 2008, 50, 1998-2006.

23 M. N. El-Haddad, RSC Adv., 2016, 6, 57844-57853.

24 S. Keera and M. Deyab, Colloids Surf., A, 2005, 266, 129.

25 A. M. Hassan and T. M. Hesham Abdel-Fatah, Int. J. Electrochem. Sci., 2016, 11, 6959-6975.

26 S. Abd El Rehim, H. Hassan and M. Amin, Mater. Chem. Phys., 2002, 78, 337.

27 M. G. A. Khedr and M. S. Lashien, Corros. Sci., 1992, 33, 137151.

28 S. S. Abd El-Rehim, H. H. Hassan and M. A. Amin, Corros. Sci., 2004, 46, 5-25.

29 J. R. Macdonald, Impedence Spectroscopy, Jhon Wiley \& Sons, New York, 3rd edn, 1987.

30 J. M. Abd El-Kader, A. A. El-Warraky and A. M. Abd El-Aziz, Br. Corros. J., 1998, 33(2), 139.

31 M. A. Migahed, M. Abd-El-Raouf a, A. M. Al- Sabagh a and H. M. Abd-El-Bary, Electrochim. Acta, 2005, 4683-4689. 
32 W. Li, Q. He, S. Zhang, C. Pei and B. Hou, J. Appl. Electrochem., 2008, 38, 289-295.

33 SingH, E. E. Ebenso and M. A. Quraishi, Int. J. Electrochem. Sci., 2012, 7, 3409-2414.

34 I. Ahamad and M. Quraishi, Corros. Sci., 2009, 51, 20062013.

35 J. Aljourani, K. Raeissi and M. A. Golozar, Corros. Sci., 2009, 51, 1836-1843.

36 H. M. Abd El-Lattef, V. M. Abbasov, L. I. Aliyeva, E. E. Qaismov and I. T. Ismayilov, Mater. Chem. Phys., 2013, 142, 502.

37 R. Mehdaoui, A. Khelifa, A. Khadraoui, O. Aaboubi, A. Hadj Ziane, F. Bentiss and A. Zarrouk, Res. Chem. Intermed., 2016, 42, 5509-5526.

38 S. Zhang, Z. Tao, W. Li and B. Hou, Appl. Surf. Sci., 2009, 255, 6757-6763.

39 M. Outirite, M. Lagrenee, M. Lebrini, M. Traisnel, C. Jama, H. Vezin and F. Bentiss, Electrochim. Acta, 2010, 55, 16701681.

40 G. E. Badr, Corros. Sci., 2009, 51, 2529-2536.

41 I. Ahamad, R. Prasad and M. A. Quraishi, Corros. Sci., 2010, 52, 1472-1481.

42 F. Bentiss, M. Outirite, M. Traisnel, H. Vezin, M. Lagrenee, B. Hammouti, S. S. Al-Deyab and C. Jama, Int. J. Electrochem. Sci., 2012, 7, 1699-1723.

43 L. R. Chauhan and G. Gunasekaran, Corros. Sci., 2007, 49, 1143-1161.

44 R. Ansari, M. A. Quraishi and A. Singh, Corros. Sci., 2014, 79, 5-.

45 E. Chaieb, A. Bouyanzer, B. Hammouti and M. Benkaddour, Appl. Surf. Sci., 2005, 246, 199-206.

46 M. Tourabi, K. Nohair, M. Traisnel, C. Jama and F. Bentiss, Corros. Sci., 2013, 75, 123-133.

47 D. A. Lopez, S. N. Simison and S. R. de Sanchez, Electrochim. Acta, 2003, 48, 845-854.

48 Z. Lukacs, J. Electroanal. Chem., 1999, 464, 68-75.
49 A. S. Fouda, A. A. Ibrahim and W. T. El- behairy, Pharma Chem., 2014, 6(5), 144-157.

50 A. S. Fouda, A. M. El-desoky and D. M. Ead, Int. J. Electrochem. Sci., 2013, 8, 8823-8847.

51 A. S. Fouda, A. A. Nazeer and A. Saber, J. Korean Chem. Soc., 2014, 58(2), 160-168.

52 K. F. Khaled and N. S. Abdel-Shafi, Int. J. Electrochem. Sci., 2013, 8, 1409-1421.

53 K. S. Ashish and M. A. Quraishi, Corros. Sci., 2011, 53(4), 1288-1297.

54 H. Vashisht, I. Bahadur, S. Kumar, M. S. Goyal, G. Kaur, G. Singh, L. Katata and E. E. Ebenso, J. Mol. Liq., 2016, 224, 19-29.

55 C. Mary Anbarasi and S. Rajendran, Res. J. Chem. Sci., 2012, 2(12), 21-26.

56 S. Gowri, J. Sathiyabama, S. Rajendran, Z. Robert Kennedy and S. Agila Devi, Chem. Sci. Trans., 2013, 2(1), 275-281.

57 R. M. Silverstein, G. C. Bassler and T. C. Morrill, Spectrometric, Identification of organic Compounds, JohnWilley and Sons, New York, NY, vol. 95, 1986.

58 J. Jeyasundari, S. Rajendran, R. Sayee Kannan and Y. Brightson Arul Jacob, Eur. Chem. Bull., 2013, 2(9), 585-591.

59 O. Obi-Egbedia and I. B. Obotb, Arabian J. Chem., 2013, 6, 211-223.

60 M. A. Deyab, Int. J. Hydrogen Energy, 2013, 38, 13511-13519.

61 S. Thomas, N. V. Medhekar, G. S. Frankel and N. Birbilis, Curr. Opin. Solid State Mater. Sci., 2015, 19, 85-94.

62 M. A. Deyab, J. Power Sources, 2013, 242, 86-90.

63 R. Solmaz, E. Altunbas and G. Kardas, Mater. Chem. Phys., 2011, 125, 796-801.

64 A. Youse, S. Javadian, N. Dalir, J. Kakemam and J. Akbari, RSC Adv., 2015, 5, 11697-11713.

65 M. A. Deyab, J. Power Sources, 2014, 268, 765-770.

66 C. Y. Chao, L. F. Lin and D. D. A Macdonald, J. Electrochem. Soc., 1981, 128(6), 1187-1194.

67 G. N. Mu, T. P. Zhao, M. Liu and T. Gu, Corrosion, 1996, 52(11), 853-856. 